\title{
PROGNOSIS CRITERIA OF THE SEVERE POSTEMBOLIZATION SYNDROME IN PATIENTS WITH UTERINE MYOMA
}

Nurmukhametova ET $\bowtie$, Shlyapnikov ME

REAVIZ Medical University, Samara, Russia

\begin{abstract}
Recently specialists take an interest in organ-preserving methods of uterine fibroids treatment, one of which is uterine artery embolization (UAE). One of the method's negative aspects is the severe postembolization syndrome (PES) development, requiring timely initiation of adequate treatment in order to avoid severe complications that could lead to the organ removal. The study was aimed to search for the prognostic criteria of the severe PES development during the preoperative period. The study included 81 UAE-treated women aged 19-50 with 7-17 week uterine myoma. The patients' anthropometric measurements were used, as well as the skin microcirculation data obtained by laser Doppler flowmetry together with the occlusion test. Based on prognostic criteria, models with AUC (area under ROC curve) $>0.8$ were presented. According to the models, the anthropometric predictors of the severe PES were the following: age under $38.5(p<0.05)$; BMI lower than $25 \mathrm{~kg} / \mathrm{m}^{2}(p<0.05)$, and microcirculation value (M) prior to UAE below $9.55 \mathrm{PU}(p=0.001)$. Microvascular blood flow during the occlusion test indicate that the higher the oxygen consumption index (I), intravascular resistance (Rc), capillary blood flow reserve capacity in the models, the higher the risk of the severe PES development $(p<0.05)$. Low alpha angle value obtained by the occlusion test $(p=0.003)$ as well as the UVLF value $(p=0.004)$ in the models also indicate the increased risk of severe PES. Multidimensional prognostic modelling admits to expect the severe PES development prior to UAE, which allows the doctor to prepare the woman for specific management and treatment.
\end{abstract}

Keywords: uterine fibroids, uterine artery embolization, postembolization syndrome, laser Doppler flowmetry, prognostic criteria

Acknowledgements: to MV Komarova, PhD, Associate Professor of the Samara University Department of Laser and Biotechnological Systems, for assistance in the statistical processing of the results.

Author contribution: Nurmukhametova ET, Shlyapnikov ME — the authors contributed to the study and manuscript writing equally.

Compliance with ethical standards: the study was approved by the Ethics Committee of the REAVIZ Medical University (protocol № 2 dated January 14, 2019). All patients submitted the informed consent to participation in the study and data publishing.

$\triangle$ Correspondence should be addressed: Elmira T. Nurmukhametova

Chkalova, 100, Samara, 443001; nurelm@yandex.ru

Received: 31.12.2019 Accepted: 19.01.2020 Published online: 29.01.2020

DOI: $10.24075 /$ brsmu.2020.006

\section{ПРОГНОСТИЧЕСКИЕ КРИТЕРИИ РАЗВИТИЯ ТЯЖЕЛОГО ПОСТЭМБОЛИЗАЦИОННОГО СИНДРОМА У ПАЦИЕНТОК С МИОМОЙ МАТКИ}

Э. Т. Нурмухаметова $\bowtie$, М. Е. Шляпников

Медицинский университет «Реавиз», Самара, Россия

В последние годы проявляется интерес к органосохраняющим методам лечения миомы матки, одним из которых является эмболизация маточных артерий (ЭМА). Среди отрицательных сторон метода — развитие тяжелого постэмболизационного синдрома (ПЭС), требующего своевременного начала адекватного лечения с целью избежания грозных осложнений, способных привести к удалению органа. Целью исследования был поиск прогностических критериев развития тяжелого ПЭС в дооперационном периоде. В исследование вошла 81 женщина с миомой матки 7-17 недель В возрасте 19-50 лет, прошедшая лечение методом ЭМА. В работе использовали антропометрические данные пациенток и показатели кожной микроциркуляции, полученные методом лазерной допплеровской флоуметрии (ЛДФ) с проведением окклюзионной пробы (ОП). На основании прогностических критериев построены модели с AUC (область под графиком ROC кривой) > 0,8. Антропометрические предикторы тяжелого ПЭС в моделях: возраст менее 38,5 лет $(p<0,05)$; ИМТ менее 25 кг/м² (p < 0,05) и показатель микроциркуляции (М) до ЭМА - менее 9,55 пф. ед. ( $p=0,001)$. Показатели микрокровотока в ОП свидетельствуют о том, что чем выше значения индекса потребления кислорода (I), внутрисосудистого сопротивления (Rc), резерва капиллярного кровотока (РКК) в моделях, тем выше риск развития тяжелой формы ПЭС ( $<<0,05)$. Низкие показатели угла альфа в ОП ( $p=0,003)$ и эндотелиальных колебаний UVLF ( $p=0,004)$ в моделях также ведут к повышенному риску развития тяжелого ПЭС. Многомерные прогностические модели позволят диагностировать развитие тяжелого ПЭС до проведения ЭМА и подготовить пациентку к определенному послеоперационному ведению и лечению.

Ключевые слова: миома матки, эмболизация маточных артерий, постэмболизационный синдром, лазерная допплеровская фллометрия, прогностические критерии

Благодарности: к. б. н., доценту кафедры лазерных и биотехнических систем Самарского университета М. В. Комаровой за консультативную помощь в статистической обработке результатов исследования.

Вклад авторов: Э. Т. Нурмухаметова, М. Е. Шляпников - равнозначен на всех этапах работы и написания статьи.

Соблюдение этических стандартов: исследование одобрено этическим комитетом медицинского университета «Реавиз» (протокол № 2 от 14 января 2019 г.). Все пациентки подписали информированное добровольное согласие на участие в исследовании и публикацию данных.

$\bowtie$ Для корреспонденции: Эльмира Тимеровна Нурмухаметова

ул. Чкалова, д. 100, г. Самара, 443001; nurelm@yandex.ru

Статья получена: 31.12.2019 Статья принята к печати: 19.01.2020 Опубликована онлайн: 29.01.2020

DOI: 10.24075 /vrgmu.2020.006

Uterine fibroids occupy a leading position in the structure of gynecological diseases, they are diagnosed in $20-50 \%$ of women of reproductive age [1], and also in 18-56\% of patients with impaired fertility [2]. Uterine fibroids worsen the women of reproductive age quality of life due to uterine bleeding, chronic anemia, lower abdominal pain, pressure on the neighboring organs and deterioration of their functions in the form of the urinary system and gastrointestinal tract function impairment. The treatment main method is the surgical removal of the uterus, which patients and doctors do not always agree with [1]. Recently the 
organ preservation techniques have been accepted [2]. Surgical procedures, such as myomectomy via laparoscopy, laparotomy, by the vaginal route, are performed under general anesthesia. There is a minimally invasive endovascular technique requiring no general anesthesia and incision, the uterine artery embolization (UAE). This endovascular technique is minimally invasive, and does not require general anesthesia, which is attractive for patients and doctors. Due to the uterine fibroid's vessels embolization, the nutrition of the nodule is disrupted, which leads to its acute hypoxia and necrosis, acidosis and the absorption of tissue degradation products into the bloodstream. In response to this, in $96 \%$ of patients during their early postoperative period (8-36 hours) the postembolization syndrome (PES) of varying severity develops [3]. The PES severity assessment is performed using the scale presented by YuE Dobrokhotova et al. [3]. The mild and moderate PES treatment is limited by the appointment of nonopioid analgesics and non-steroidal anti-inflammatory drugs orally, as well as by hospitalization for 1-3 days. In patients with severe PES, opioid analgesics, antibiotic intravenous infusion therapy, correction of coagulation are used. If necessary, the urinary bladder catheterization and other methods are used. The patients with severe PES are at high risk of the severe complications, such as metrorrhagia, pyometra, sepsis and thrombosis which can lead to the organ removal [4-6]. Thus, the question of timely initiation of corrective therapy in the severe PES patients remains important, which would facilitate a milder progression of the disease, serve as a prophylaxis of complications and create a favorable opinion of this treatment method in the patient. Methods have been proposed to reduce pain in the early postoperative period, as pain is the main symptom. During the UAE procedure, it was proposed to administer $100 \mathrm{mg}(2.5 \mathrm{ml})$ of Actovegin prior to the emboli administration in order to increase the uterus parenchymal blood flow, thereby reducing the PES manifestations [7]. Other authors recommend to calculate the minimum number of embolic agents' portions accurately, to reduce the number of complications associated with an overdose of particles, as well as the cost of the procedure due to the price of emboli [8]. The severity of PES can be reduced by the use of varicose veins therapy in the postoperative period, especially in patients with uterine fibroids, suffering from venous and lymphatic insufficiency of the lower extremities [9]. During our study we analyzed the history of patients admitted to UAE and found that age, BMI and nodule location were statistically significant factors affecting the progression of PES. The latter is a qualitative parameter, therefore anthropometric data (quantitative) were used in the prognostic models. Among the examination methods, we distinguished laser Doppler flowmetry (LDF) which was used in the acute period in patients with uterine myoma prior to UAE for the first time. The available literature sources contain data on the study of skin microcirculation in gynecological patients with chronic diseases, but contain no data on the acute diseases [10]. Since PES is the body's response to the UAE procedure, it is a systemic response. LDF reflects changes in skin microcirculation, which characterize whole body's condition [11]. The severe PES development is associated with the risk of complications and with the pronounced influence on the patients' general wellbeing, unlike the mild and moderate PES. The study was aimed to determine the severe PES development prognostic criteria using the anthropometric data and skin microcirculation data prior to UAE.

\section{METHODS}

In 2016-2019 at the RZHD-Medicina Clinical Hospital, 81 patients aged $18-50$ with 7-17 week symptomatic growing uterine fibroids were surveyed (nodule size $21-115 \mathrm{~mm}$ ). The average age of the patients was $39 \pm 6$.

Inclusion criteria: progressive uterine myoma; clinical symptoms in the form of menometerorrhagia, lower abdomen "dragging" pain; compression of the neighbouring organs associated with frequent urination and constipation; lack of historical data on the conservative therapy effect; woman's decidedness to save the uterus for various reasons: psychological comfort, possible reproductive planning, high risk of surgery, "fear" of general anesthesia and surgery.

All the women were treated by UAE because of the indications. In the early postoperative period the surveyed patients were divided into 3 groups in accordance with the PES severity: mild PES (group I), 36 (44.44\%) patients, moderate PES (group II), 30 (37.04\%) patients, pronounced PES (group III), $15(18.52 \%)$ patients. In patients with multiple myomas, the the dominant nodule was evaluated. The single nodule uterine fibroid sized $30-110 \mathrm{~mm}$ was revealed in 41 (50.6\%) patients, the other 40 patients $(49.4 \%)$ had multiple myomas with the nodules sized $21-115 \mathrm{~mm}$. There were no significant differences between the groups ( $\left.p=0.705 ; \chi^{2}=0.7\right)$.

Exclusion criteria (due to factors affecting the UAE procedure): pelvic inflammatory disease; history of the gonadotropinreleasing hormone agonist or hormone drugs intake (hormonal contraception or hormone replacement therapy) less than the 3 months before the study; pelvic malignant tumors; grade III adenomyosis; allergic reactions to contrast material; negative Allen test; presence of the arteriovenous fistula for the dialysis; Buerger's disease.

Exclusion criteria (due to the factors affecting the LDF results): cardiovascular diseases and severe atherosclerotic vascular disease; diabetes mellitus; chronic venous insufficiency; Raynaud's disease; obliterating endarteritis; injuries; deformations and infectious lesions of the distal phalanx [11].

For patients with submucous and subserous myomas (FIGO (2011) types 0, 1, 6 and 7) other treatment methods were recommended instead of UAE: myomectomy via resectoscopy, laparoscopy, by the vaginal route. The UAE was performed via femoral artery (according to Seldinger technique) in 63 patients, and via radial artery in 18 patients, using the Embosphere microspheres (Biosphere Medikal; USA) sized 500-1200 $\mu \mathrm{m}$. UAE method, bottles' number and emboli size were determined by the $\mathrm{X}$-ray surgery specialist after consulting the patient and during the diagnostic and therapeutic arterial interventions.

The patients were examined in accordance with the generally accepted scheme: general medical examination, ultrasound with the color Doppler imaging, consultations of the gynecologist, therapist and X-ray surgery specialist, diagnostic D\&C or endometrial aspiration with the histopathological examination. In the early postoperative period, the patients develop a symptom complex called postembolization syndrome (PES), characterized by pain of varying intensity, high body temperature, elevated ESR, leukocytosis, impaired cardiovascular function (tachycardia), impaired gastrointestinal tract function (nausea, vomiting, intestinal paresis), impaired urinary tract function (urinary retention), impaired blood coagulation (hyperfibrinogenemia), bloody discharge.

The microcirculation system condition was evaluated prior to UAE by LDF and the occlusion test, which is the closest to the UAE procedure, using the LAKK-O2 unit (Lazma; Russia). Investigation was performed after acclimatization, lasting for 30 minutes in the room with the $21-24^{\circ} \mathrm{C}$ temperature. The patients were not allowed to smoke, eat or drink anything that could affect the microcirculation before the examination. The study was carried out in the same room at the same 
time (lunch from 12 to13 h; study from 15 to $17 \mathrm{~h}$ ), outside of menstruation. The patient was in her sitting position, the upper limb in moderate flexion was placed on the table, sensor was installed in the eponychium of the right hand $3^{\text {rd }}$ finger, while the hand was at heart level. For the occlusion test, the tonometer cuff was fixed on the shoulder of the right hand. The test was carried out as follows: within one minute, the baseline blood flow was recorded, then the recording was stopped. After that, the occlusion was created by quick pumping up the pressure in the cuff to the level of 230-250 $\mathrm{mm} \mathrm{Hg}$. The further registration of the blood flow for 3 minutes of the occlusion period was carried out. After a 3-minute occlusion, air was quickly released from the cuff, during the next 6 minutes the perfusion reaction was recorded while the blood flow restored [11].

The data acquired during the study were processed using the software coming with the equipment used. The following indicators were evaluated: $M$, arithmetic mean value of microcirculation measured in perfusion units (PU); $\sigma$, standard deviation (RMS) of the blood flow oscillations amplitude from the $M$ arithmetic mean value; using the wavelet transform, the following indicators: UVLF, VLF, LF, HF, CF, blood flow oscillations of the frequency bands corresponding to endothelial, neurogenic, myogenic, respiratory, cardiac activities respectively (PU); capillary blood flow reserve capacity; $\alpha$,

Table. 1. Dominant myoma size and localization

\begin{tabular}{|c|c|c|c|c|c|c|c|}
\hline \multirow[b]{2}{*}{ FIGO myoma classification, 2011} & \multicolumn{3}{|c|}{ PES severity } & \multicolumn{3}{|c|}{ Intergroup comparison } & \multirow{2}{*}{$\begin{array}{l}\text { Whole table } \\
\text { comparison, } p\end{array}$} \\
\hline & $\begin{array}{l}\text { Mild }(n=36) \\
\text { Abs. }(\%)\end{array}$ & $\begin{array}{c}\text { Moderate }(n=30) \\
\text { Abs. }(\%)\end{array}$ & $\begin{array}{l}\text { Severe }(n=15) \\
\quad \text { Abs. }(\%)\end{array}$ & $p^{1-2}$ & $p^{1-3}$ & $p^{2-3}$ & \\
\hline $\begin{array}{l}\text { Intramural myoma, up to } 50 \% \text { in the } \\
\text { uterine cavity (type 2) }\end{array}$ & $16(44.4 \%)$ & $8(26.7 \%)$ & $6(40.0 \%)$ & 0.216 & 0.985 & 0.569 & \multirow{4}{*}{0.020} \\
\hline Intramural myoma (type 4) & $16(44.4 \%)$ & $11(36.7 \%)$ & $1(6.7 \%)$ & 0.698 & 0.023 & 0.074 & \\
\hline $\begin{array}{l}\text { Subserous myoma, up to } 50 \% \text { in the } \\
\text { abdominal cavity (type } 5 \text { ) }\end{array}$ & $3(8.3 \%)$ & $6(20.0 \%)$ & $6(40.0 \%)$ & 0.310 & 0.021 & 0.283 & \\
\hline Isthmic myoma (type 8) & $1(2.8 \%)$ & $5(16.7 \%)$ & $2(13.3 \%)$ & 0.127 & 0.420 & 0.885 & \\
\hline Number of myomas & $1.53 \pm 1.02$ & $2.15 \pm 1.50$ & $2.62 \pm 1.75$ & 0.349 & 0.010 & 0.624 & 0.042 \\
\hline Size of dominant fibroid before UAE, mm & $58.32 \pm 17.30$ & $55.60 \pm 22.10$ & $54.76 \pm 17.70$ & 0.963 & 0.843 & 0.998 & 0.791 \\
\hline
\end{tabular}

Note: myoma nodules' localization comparison was performed using the Pearson $\chi^{2}$ test $\left(\chi^{2}=15.1\right)$, comparison of the nodules' number and size was performed using ANOVA.

Table. 2. Anthropometric data of patients and parameters of microcirculation at rest and during the occlusion test prior to UAE for the groups of patients with PES of different severity

\begin{tabular}{|c|c|c|c|c|c|c|c|}
\hline & $\begin{array}{c}\text { Mild PES } \\
\text { (score below 7) }\end{array}$ & $\begin{array}{l}\text { Moderate PES } \\
\text { (score 8-14) }\end{array}$ & $\begin{array}{l}\text { Severe PES } \\
\text { (score 15-21) }\end{array}$ & $p^{1-2}$ & $p^{1-3}$ & $p^{2-3}$ & $p^{\text {ANOVA }}$ \\
\hline Age, years* & $39.72 \pm 6.47$ & $42.10 \pm 5.70$ & $35.07 \pm 5.74$ & 0.310 & 0.048 & 0.002 & 0.002 \\
\hline $\mathrm{BMI}, \mathrm{kg} / \mathrm{m}^{2 \star}$ & $26.24 \pm 3.41$ & $27.86 \pm 6.39$ & $23.34 \pm 3.14$ & 0.515 & 0.020 & 0.008 & 0.013 \\
\hline \multicolumn{8}{|c|}{ Microcirculation at rest } \\
\hline $\mathrm{M}, \mathrm{PU}$ & 22.33 (12.98-24.03) & $17.55(10.38-19.15)$ & $7.90(5.40-15.60)$ & 0.110 & 0.002 & 0.011 & 0.003 \\
\hline$\sigma(\mathrm{SD}), \mathrm{PU}$ & $1.70(1.40-3.68)$ & $1.25(1.10-1.40)$ & 3.35 (1.50-3.98) & $<0.001$ & 0.278 & $<0.001$ & $<0.001$ \\
\hline VLF, PU & $0.98(0.57-1.02)$ & $0.58(0.31-0.74)$ & $0.62(0.52-0.74)$ & $<0.001$ & 0.005 & 0.268 & $<0.001$ \\
\hline LF, PU & $0.54(0.45-0.81)$ & $0.42(0.28-0.69)$ & $0.42(0.38-0.54)$ & 0.037 & 0.054 & 0.791 & 0.053 \\
\hline HF, PU & $0.17(0.14-0.19)$ & $0.16(0.13-0.22)$ & $0.16(0.14-0.17)$ & 0.583 & 0.448 & 0.837 & 0.729 \\
\hline CF, PU & $0.15(0.14-0.24)$ & $0.22(0.13-0.37)$ & $0.17(0.14-0.26)$ & 0.017 & 0.279 & 0.242 & 0.047 \\
\hline 1 & $9.45(4.67-12.25)$ & $10.93(8.96-19.47)$ & $3.88(2.61-4.88)$ & 0.017 & $<0.001$ & $<0.001$ & $<0.001$ \\
\hline Rc & $0.19(0.10-0.27)$ & $0.38(0.24-0.47)$ & $0.18(0.08-0.21)$ & $<0.001$ & 0.489 & $<0.001$ & $<0.001$ \\
\hline \multicolumn{8}{|c|}{ Blood flow during the occlusion test } \\
\hline $\mathrm{M}, \mathrm{PU}$ & $15.00(6.95-17.03)$ & $12.55(9.05-21.98)$ & $14.80(3.60-17.50)$ & 0.567 & 0.166 & 0.097 & 0.220 \\
\hline$\delta(\mathrm{SD})$ & $11.40(7.55-13.63)$ & $10.25(7.73-12.25)$ & $8.30(2.60-9.40)$ & 0.463 & 0.042 & 0.089 & 0.097 \\
\hline $\begin{array}{l}\text { Capillary blood flow } \\
\text { reserve capacity, \% }\end{array}$ & $166.21(139.95-219.05)$ & $136.31(128.33-174.04)$ & $220.09(134.40-245.11)$ & 0.008 & 0.414 & 0.013 & 0.008 \\
\hline$\alpha$-Angle & $65.89(54.19-69.27)$ & $50.22(48.35-65.73)$ & $41.11(34.92-48.22)$ & 0.051 & $<0.001$ & $<0.001$ & $<0.001$ \\
\hline UVLF & $3.15(2.63-3.72)$ & $2.76(2.29-3.74)$ & $1.76(1.21-2.65)$ & 0.241 & $<0.001$ & 0.002 & $<0.001$ \\
\hline VLF & $1.75(1.46-2.61)$ & $1.75(1.23-2.41)$ & $1.33(0.81-1.64)$ & 0.312 & 0.001 & 0.006 & 0.003 \\
\hline LF & $0.78(0.63-1.13)$ & $0.95(0.46-1.01)$ & $1.00(0.32-1.09)$ & 0.279 & 0.282 & 0.981 & 0.432 \\
\hline $\mathrm{HF}$ & $0.23(0.13-0.32)$ & $0.23(0.17-0.32)$ & $0.27(0.12-0.44)$ & 0.588 & 0.694 & 0.923 & 0.843 \\
\hline CF & $0.15(0.13-0.19)$ & $0.16(0.11-0.24)$ & $0.16(0.12-0.23)$ & 0.380 & 0.413 & 0.904 & 0.592 \\
\hline 1 & $5.90(4.33-7.28)$ & $7.77(4.68-8.42)$ & $4.68(1.82-9.20)$ & 0.039 & 0.942 & 0.253 & 0.125 \\
\hline Rc & $0.04(0.03-0.04)$ & $0.04(0.03-0.07)$ & $0.06(0.05-0.09)$ & 0.124 & $<0.001$ & 0.004 & $<0.001$ \\
\hline
\end{tabular}

Note: * — data are presented as standard deviation $\mathrm{M} \pm \mathrm{SD}$; other data are presented as median and interquartile range. 
reactive hyperemia curve angle; I, tissue oxygen consumption index; Rc, intravascular resistance.

Statistical processing of the data acquired was performed using the SPSS 21 software (IBM SPSS; USA). Descriptive statistics for quantitative indicators were presented as mean $\mathrm{M}$ and standard deviation $\mathrm{M} \pm \mathrm{SD}$. If the distribution was skewed, the data was presented as median and interquartile range. For comparison of groups, we used one-way analysis of variance (ANOVA) or its nonparametric analogue, the KruskelWallis test, together with the intergroup comparison using the Mann-Whitney-Wilcoxon test and Bonferroni correction. Pearson $\chi^{2}$ test was used for the nominal data comparison. To assess the contribution of individual characteristics to the risk of severe PES, one-dimensional and multi-dimensional logistic regression was used. The quality of prognosis was evaluated using ROC analysis. The results were considered significant when $p<0.05$.

\section{RESULTS}

Prior to UAE, in the studied groups, no significant differences were revealed in the patients' history, complaints, examination data, myoma size $\left(p_{\text {ANOVA }}=0.607\right)$, and the dominant nodule size $\left(p_{\text {ANOVA }}=0.897\right)$. There were differences in the localization and number of myoma nodules (Table 1).

It was found, that in women with low baseline skin microcirculation value, $\mathrm{M}$ (7.90 PU) and high perfusion variability value (3.35 PU), severe PES was revealed after UAE (Table 2). The amplitude and frequency spectrum of blood flow oscillations at rest had no diagnostic value. During the occlusion test, the endothelial and neurogenic components (active microcirculation mechanisms associated with blood flow) could be the severe PES predictors. In particular, the UVLF oscillations value during the occlusion test (endothelial) in the group III was 1.76 PU, which was significantly lower than the values in the group I (3.15 PU.; $\left.p_{1-3}<0.001\right)$ and II (2.76 PU; $\left.p_{2-3}=0.002\right)$; the VLF oscillations value during the occlusion test (neurogenic) in the group of patients with severe PES was lower than in the groups of patients with mild $\left(p_{1-3}=0.001\right)$ and moderate $\left(p_{2-3}=0.006\right)$ PES.

The statistically significant differences in anthropometric characteristics revealed (age, BMI), as well as skin microcirculation parameters ( $\mathrm{M}$ at rest, $\delta$ at rest, capillary blood flow reserve capacity during the occlusion test, $\alpha$-angle during the occlusion test, UVLF during the occlusion test, VLF during the occlusion test, Rc during the occlusion test) before the procedure became the basis for the most significant risk factors and predictors identification (see Table 2). Logistic regression was a mathematical tool for evaluation of the studied protective factors influence on PES. Predicting the risk of severe PES compared with mild or moderate PES was carried out without dividing the last two categories. At the first stage, one-dimensional models were constructed for the main blood flow parameters, the predictors were forced into the model (Table 3).

During the study, we identified a number of criteria allowing one to predict the severe PES development in the early postoperative period after UAE. Among the anthropometric

Table. 3. Assessment of the anthropometric characteristics and microcirculation parameters value for predicting severe PES using the one-dimensional logistic regression model

\begin{tabular}{|c|c|c|}
\hline Predictor & OR $(95 \% \mathrm{Cl})$ & $p$ \\
\hline Anthropometric characteristics & - & - \\
\hline Age, years & $0,87(0,79-0,96)$ & 0,005 \\
\hline $\mathrm{BMI}, \mathrm{kg} / \mathrm{m}^{2}$ & $0,77(0,63-0,94)$ & 0,010 \\
\hline Microcirculation parameters at rest & - & - \\
\hline $\mathrm{M}, \mathrm{PU}$ & $0,83(0,74-0,92)$ & 0,001 \\
\hline$\delta$ & $1,70(1,09-2,64)$ & 0,019 \\
\hline VLF & $0,38(0,05-3,20)$ & 0,375 \\
\hline LF & $0,23(0,02-3,16)$ & 0,271 \\
\hline HF (step 0.1)* & $0,50(0,15-1,63)$ & 0,248 \\
\hline CF & $0,15(0,00-20,14)$ & 0,452 \\
\hline 1 & $0,58(0,42-0,80)$ & 0,001 \\
\hline $\mathrm{Rc}(\operatorname{step} 0.1)^{*}$ & $0,58(0,35-0,96)$ & 0,033 \\
\hline Microcirculation parameters during the occlusion test & - & - \\
\hline $\mathrm{M}, \mathrm{PU}$ & $0,94(0,86-1,03)$ & 0,166 \\
\hline$\delta$ & $0,82(0,71-0,96)$ & 0,014 \\
\hline Capillary blood flow reserve capacity, \% & $1,02(1,00-1,03)$ & 0,008 \\
\hline$\alpha$-Angle & $0,85(0,78-0,93)$ & $<0,001$ \\
\hline UVLF & $0,23(0,10-0,53)$ & 0,001 \\
\hline VLF & $0,14(0,04-0,53)$ & 0,004 \\
\hline LF & $0,46(0,07-3,18)$ & 0,430 \\
\hline HF $(\text { step } 0.1)^{*}$ & $1,41(0,85-2,32)$ & 0,179 \\
\hline CF & $0,87(0,00-183,07)$ & 0,959 \\
\hline I & $1,07(0,91-1,26)$ & 0,422 \\
\hline $\mathrm{Rc}^{\star \star}$ (step 0.01) & $1,68(1,27-2,21)$ & $<0,001$ \\
\hline
\end{tabular}

Note: * - odds ratio is optimized for the predictor's increase by $0.1 ;{ }^{* *}$ odds ratio is optimized for the predictor's increase by 0.01 . 
A

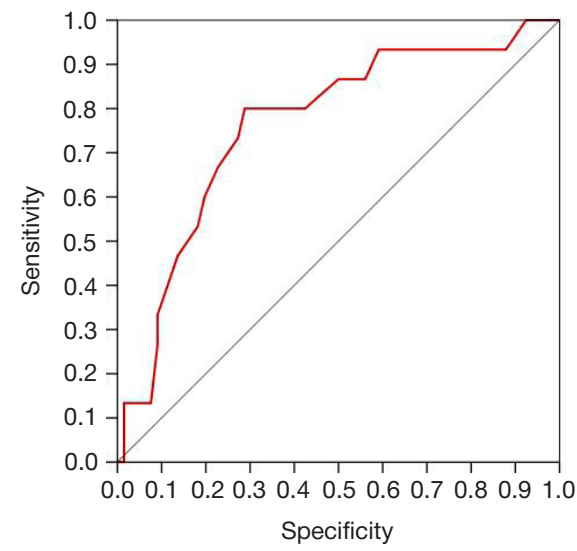

C

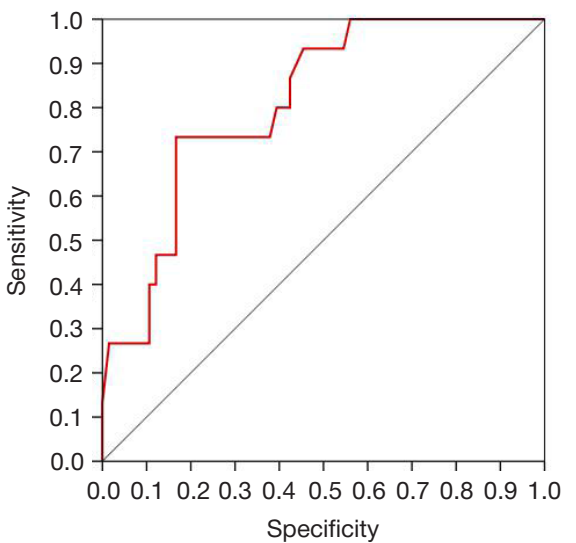

B

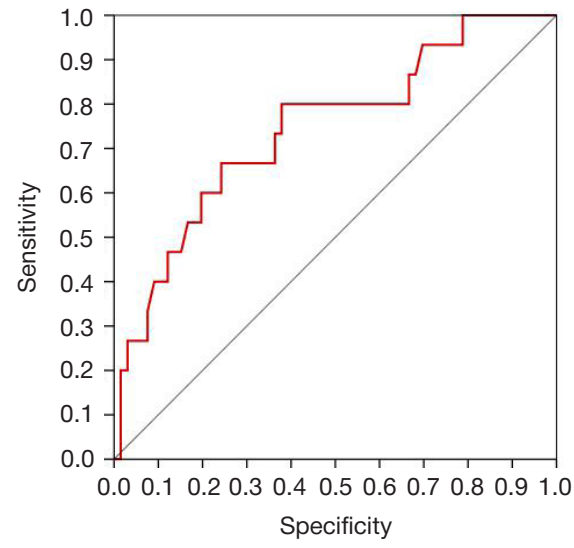

D

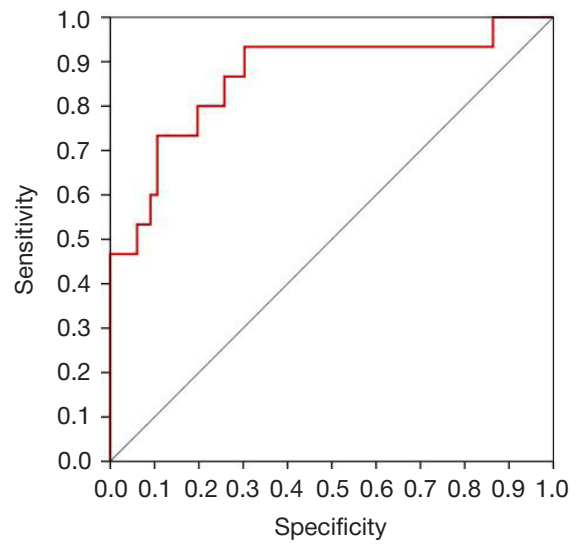

Fig. 1. ROC curves demonstrating the prognostic value of age (A), BMI (B), perfusion rate at rest (C), $\alpha$ blood flow recovery angle (D)

characteristics, the statistically significant factors affecting PES were the age of the woman and her BMI. In both parameters the odds ratio was less than one: for age $\mathrm{OR}=0.87(0.79-0.96)$, for $\mathrm{BMI} \mathrm{OR}=0.77$ (0.63-0.94), that's why they could be considered protective factors. According to the models constructed, the greater the age and BMl of the patient, the lower her risk of PES. In order to define which threshold values of the studied traits predicted the development of PES best, as well as to quantify the predictive value of each trait, the ROC curves were used (Fig. 1). The coordinates and the corresponding values of sensitivity and specificity were analyzed. It was found that women aged 38.5 years and younger were at risk of severe PES (sensitivity $80 \%$, specificity $71 \%$ ). The other risk factor of the severe PES was BMI. According to the data obtained, women with normal body weight and reduced body weight were at risk of severe PES. With the BMI threshold value of $25 \mathrm{~kg} \mathrm{~m} 2$, sensitivity of severe PES predicting was $80 \%$, and specificity was $62 \%$. The area under ROC curve for age was $0.76 \pm 0.068(p=0.002)$, and for $\mathrm{BMl}$ it was $0.74 \pm 0.073$ $(p=0.003)$.

Of the blood flow parameters at rest, the microcirculation value (M) turned out to be highly informational, the area under the ROC curve for M was $0.81 \pm 0.05(p<0.001)$. The coordinates' analysis of the ROC curve for M demonstrated that 9.55 PU was a reliable threshold value. In women with a perfusion rate at rest prior to planned procedure below 9.55 PU, severe PES development could be expected (sensitivity $73 \%$, specificity $83 \%$ ). The isolation of individual oscillations of the microvessels using the wavelet analysis at rest without any additional tests was of no predictive value for the diagnosis of severe PES.

The occlusion test, allowing one to simulate the body's response to acute hypoxia, showed a high prognostic potential of the recovery angle $\alpha$ (area under ROC curve $0.87 \pm 0.059$; $p<0.001$ ) (Fig. 1D). Fast recovery after the 3-minute occlusion reduced the risk of severe PES $(\mathrm{OR}=0.85$ (0.78-0.93); $p<0.001)$. In our opinion, the best threshold value was $\alpha=48$ (sensitivity and specificity of the prediction was $80 \%$ ).

At the next stage the multivariate logistic regression models were plotted using step-by-step selection of potential predictors (Table 4). Since various indicators of blood flow were obtained by the same signal processing, and some of them were derived from the baseline, all of them were interconnected to various extent. Therefore, several models of comparable quality were proposed (Fig. 2).

Model 1 has been plotted using the anthropometric characteristics. Prediction quality with a threshold probability of 0.25 : sensitivity $67 \%$, specificity $88 \%$. Both traits have the OR less than one, therefore, the high values are protective factors; AUC is $0.81 \pm 0.058(p<0.001)$.

Model 2 has been plotted using the anthropometric characteristics and the blood flow parameters at rest. As a result of step-by-step selection, only age and $\mathrm{M}$ were included in the model. Prediction quality with a threshold probability of 0.35 : sensitivity $73 \%$, specificity $89 \%$; AUC is $0.89 \pm 0.04$ $(p<0.001)$.

Model 3 has been plotted using the anthropometric characteristics and the occlusion test results ( $\alpha$ angle and capillary blood flow reserve capacity). $\alpha$ Angle most strongly affects the outcome of traits: its decrease is associated with the increased risk of severe PES. Prediction quality with a threshold probability of 0.25 : sensitivity $87 \%$, specificity $91 \%$; AUC is $0.93 \pm 0.042(p<0.001)$.

Model 4 is very much like model 3 . It has been plotted using the LDF values obtained during the occlusion test according to the wavelet analysis of the original signal. In accordance with the model, endothelial oscillations are the most significant protective factor: their high values decrease 
A

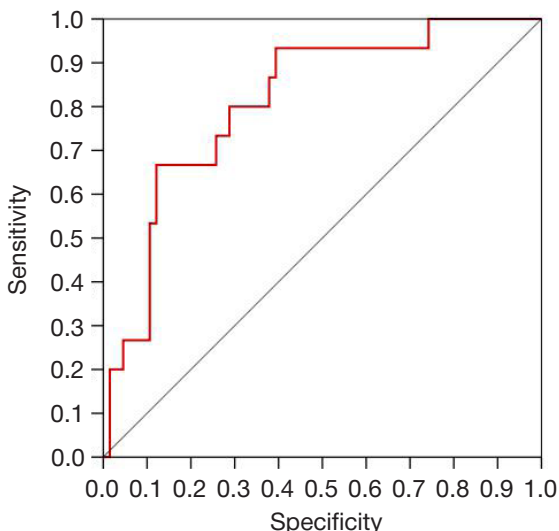

C

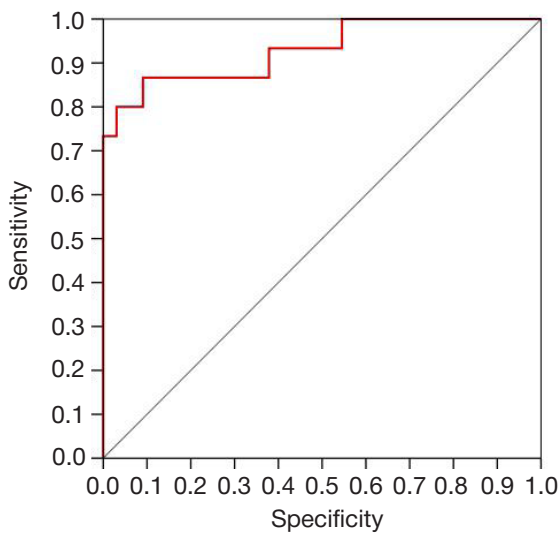

B
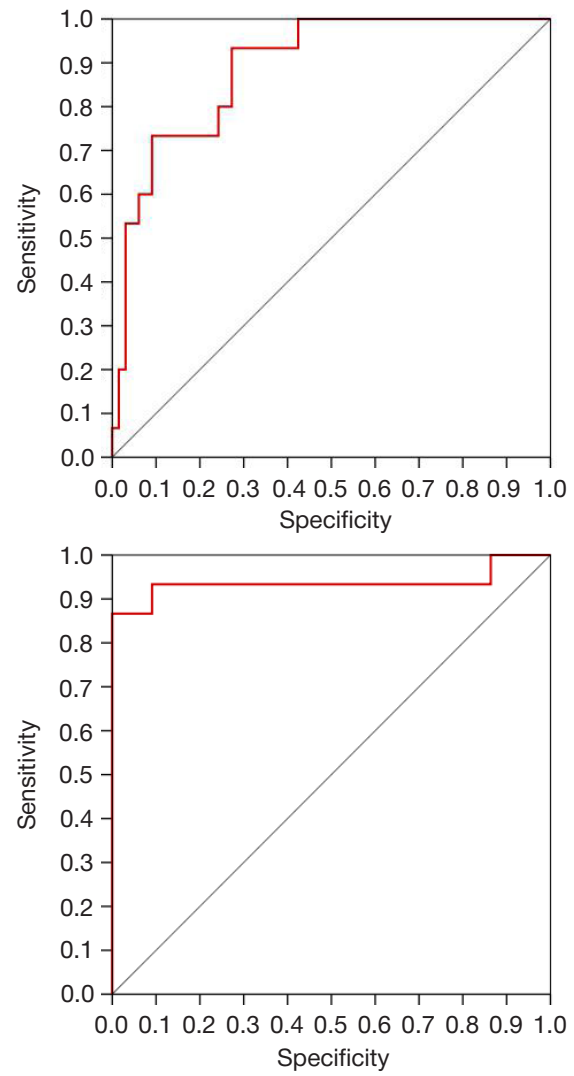

Fig. 2. ROC curves demonstrating the multivariate models prognostic value 1 (A), 2 (B), 3 (C), 4 (D)

the risk of severe PES: OR 0.09 (95\% Cl: 0.02-0.47). This corresponds the previously revealed effect of the $\alpha$ angle, which also reflects the intensity of blood flow recovery after the occlusion test. High values of I and Rc increase the risk of severe PES. Prediction quality with a threshold probability of 0.25 : sensitivity $87 \%$, specificity $98 \%$; AUC is $0.94 \pm 0.056$ $(p<0.001)$.

\section{DISCUSSION}

According to the results of other authors, severe PES develops in $10.2 \%$ of patients after EMA [3]. Our results suggest that severe PES develops in $18.52 \%$ of patients. The difference may be due to the larger number of exclusion criteria associated with LDF, i.e., diseases that impede (distort) the study of

Table. 4. Assessment of the anthropometric characteristics and microcirculation parameters for the severe PES prognosis using the multivariate logistic regression models

\begin{tabular}{|c|c|c|c|c|c|}
\hline Variables & Regression coefficient, $b$ & SE $b$ & Wald test & OR $(95 \% \mathrm{Cl})$ & $p$ \\
\hline \multicolumn{6}{|l|}{ Model 1} \\
\hline $\mathrm{BMI}, \mathrm{kg} / \mathrm{m}^{2}$ & -0.19 & 0.1 & 3.83 & $0.83(0.69-1.00)$ & 0.05 \\
\hline Age, years & -0.11 & 0.05 & 4.44 & $0.89(0.81-0.99)$ & 0.035 \\
\hline Invariable & 7.49 & 2.68 & 7.82 & - & 0.005 \\
\hline \multicolumn{6}{|l|}{ Model 2} \\
\hline $\mathrm{M}$ at rest, $\mathrm{PM}$ channel & -0.23 & 0.07 & 11.04 & $0.80(0.70-0.91)$ & 0.001 \\
\hline Age, years & -0.17 & 0.06 & 8.17 & $0.84(0.75-0.95)$ & 0.004 \\
\hline Invariable & 7.71 & 2.53 & 9.28 & - & 0.002 \\
\hline \multicolumn{6}{|l|}{ Model 3} \\
\hline$\alpha$-Angle during the occlusion test & -0.19 & 0.06 & 9.02 & $0.82(0.73-0.94)$ & 0.003 \\
\hline $\begin{array}{l}\text { Capillary blood flow reserve } \\
\text { capacity during the occlusion } \\
\text { test, \% }\end{array}$ & 0.03 & 0.01 & 5.62 & $1.03(1.00-1.05)$ & 0.018 \\
\hline Age, years & -0.16 & 0.08 & 4.41 & $0.85(0.74-0.99)$ & 0.036 \\
\hline Invariable & 9.42 & 3.91 & 5.81 & - & 0.016 \\
\hline \multicolumn{6}{|l|}{ Model 4} \\
\hline UVLF during the occlusion test, PU & -2.35 & 0.81 & 8.42 & $0.09(0.02-0.47)$ & 0.004 \\
\hline I during the occlusion test & 0.56 & 0.21 & 6.81 & $1.74(1.15-2.64)$ & 0.009 \\
\hline Rc during the occlusion test ${ }^{\star}$ & 62.64 & 23.22 & 7.28 & $1.87(1.19-2.95)$ & 0.007 \\
\hline Age, years & -0.18 & 0.08 & 5.12 & $0.83(0.71-0.98)$ & 0.024 \\
\hline Invariable & 3.91 & 3.7 & 1.12 & - & 0.290 \\
\hline
\end{tabular}


microvessel blood flow at the nail bed. It is known that the reaction to the same stimulus is more pronounced in youngsters than in older people [12], which, for example, is evidenced by self-assessment using the pain VAS. Perhaps this explains that in the group of patients with severe PES, the average age of women was lower $(35.07 \pm 5.74)$, which was considered the risk factor ( $p=0.005$ ). BMI less than $25 \mathrm{~kg} / \mathrm{m}^{2}$ was also a risk factor of the severe PES development. According to our results, in overweight individuals, the microcirculation rate is higher, which contributes to milder PES, while all body systems work in an increased regulatory and compensatory mode, and therefore the metabolic load that occurs after UAE is more easily tolerated [12]. According to other data, in $2.8 \%$ of patients with myoma size under 12 weeks and in $7.3 \%$ of patients with myoma sized over 12 weeks the persistent intestinal paresis with vomiting was observed, which was associated with the reflex action of ischemic areas of the uterus on neighbouring organs, or transient intestinal ischemia as a result of accidental partial embolization of the superior mesenteric artery [3]. In our study, the average size of the dominant nodule was small, and there were no significant differences between the groups (see Table 1) due to the design of the study. Although, the nodules size correlated with the pain severity [13]. We noted that the myoma nodules' localization affected the postoperative period course. The subserous nodules' prevalence in the group of patients with severe PES was a risk factor, since ischemic nodules irritated the intestinal loops, led to nausea, bloating and other manifestations of gastrointestinal tract function impairment after UAE, thereby making PES worse in the early postoperative period (see Table 1). An increase in the amount and duration of bloody discharge (one of the PES symptoms) was caused by uterine fibroids of the submucous and interstitial localization that prevailed in group III [14].

In women with a perfusion rate at rest below 9.55 PU prior to the procedure, the more severe PES was observed. The $M$ value in most of women with severe PES was lower compared with women with milder PES: $53.3 \%$ versus $11.1 \%$ $(p=0.004)$ and $23.3 \%(p=0.094)$. Other researches obtained similar data, the low $\mathrm{M}$ value was also considered a risk factor of postoperative complications, in comparison with a group with a high $\mathrm{M}$ [15]. This may explain the fact that in patients with reduced $\mathrm{M}$, in order to maintain normal microcirculation function under conditions of changing body metabolism with the development of severe PES, there is an increase in microcirculation and its regulation (this takes time). It can be assumed that in patients with high $M$ value, the severe PES probability is lower, since microcirculation in the whole body is good and it does not take time to involve regulation mechanisms to maintain homeostasis $[12,16]$. Blood flow oscillations, UVLF, VLF, LF, HF, CF (Table 3) at rest, were of no prognostic value. During the occlusion test the endothelial and neurogenic blood flow oscillations changes were detected [17]. Since the occlusion test reflects the intensity of blood flow recovery and the microvessels reserve capabilities, the indicators evaluated have a high prognostic value. After the 3-minute cessation of blood flow during decompression, blood flow in the artery is restored and reactive hyperemia develops (capillary blood flow reserve capacity, $\alpha$ angle, oxygen consumption index), which leads to the vasodilation causing endothelial production of nitric oxide stimulation through a neurogenic reaction $[11,16]$. Slow microvessel blood flow recovery was a severe PES risk factor. Based on the data obtained, multivariate prognosis models were plotted.

\section{CONCLUSION}

In our study, we plotted four severe PES prognosis models. The multivariate models included the severe PES risk factors. Anthropometric characteristics, such as age under 38.5 and BMI lower than $25 \mathrm{~kg} / \mathrm{m}^{2}$ were included into the models. Among the microcirculation parameters obtained using LDF one need to pay attention to the background microcirculation level. When the $\mathrm{M}$ value at rest is under $9.55 \mathrm{PU}$, there is a high risk of severe PES. Models 1 and 2 plotted using the anthropometric characteristics and the background $\mathrm{M}$ level demonstrate AUC limited by $0.8-0.9$, which can be considered "very good". Models 3 and 4 with AUC limited by 0.9-1.0 ("excellent") use the microcirculation data obtained under the load (occlusion test) prior to UAE, which are of great prognostic value. The higher are the I, Rc and capillary blood flow reserve capacity values during the occlusion test, the higher is the risk of severe PES. On the contrary, the low value of $\alpha$ angle during the occlusion test and low value of the UVLF oscillations are associated with the higher risk of severe PES. The doctor can use these prognostic models in his daily practice consulting the patients on the possible PES course and planning the treatment scheme in the earlier period after UAE, thereby facilitating the patient's well-being during the postoperative period.

\section{References}

1. Adamyan LV, Serov VN, Sukhikh GT, Filippov OS, redactory. Klinicheskiye rekomendatsii. Akusherstvo i ginekologiya. Problemy reproduktsii. Spets vyp. 2017; 23 (6). Russian.

2. Shapovalova A. I. Lejomioma matki i reprodukciya. Zhurnal akusherstva i zhenskix boleznej. 2019; 68 (1): 93-101. https:// doi.org/10.17816/JOWD68193-101). Russian.

3. Dobrohotova YuE, redaktor. Embolizaciya matochnyh arterij. Spb: Eksten Medikal, 2013; 112 s. Russian.

4. Marín-Sánchez P, Sánchez-Ferrer ML. Conservative management of vesical-vaginal fistula after partial uterine and bladder necrosis due to embolization as a treatment for postpartum hemorrhage. Int Urogynecol J. 2015; 26 (5): 773-4. DOl: 10.1007/s00192-014-2617-1.

5. Pillai AK, Kovoor JM, Reis SP, et al. Exposure of a Uterine Fibroid into the Small Bowl through Uteroenteric Fistula Presenting with Bowel Obstruction after Uterine Fibroid Embolization: Case Report with Histopathological Correlation. J Vasc Interv Radiol. 2016; 27 (5): 762-4. DOI: 10.1016/j. jvir.2015.11.047.

6. Yu Q, Gabriel G, Hoffman M, Sanampudi S, Jassim T, Raissi D.
Uterine-sparing management of pyomyoma after uterine fibroid embolization. Radiol Case Rep. 2019 Jun 12; 14 (8): 1031-5. DOI: 10.1016/j.radcr.2019.05.009.

7. Goryunova TV, Agapov VK, Cvirkun VV, GoloshchapovAksenov RS, Skrubert VS, Klimov MM, avtory; Goryunova TV, patentoobladatel'. Sposob lecheniya miomy matki. Patent RF № 2289415, A61K35/14, 20.12.2006. Russian.

8. Pirogova VI, Galanova ZM, Garipov RM, Muhametvaleeva GR, Galimov OV, Buzaev IV, i dr, avtory; Bashkirskij gosudarstvennyj medicinskij universitet, petentoobladatel'. Sposob profilaktiki posleoperacionnyh oslozhnenij embolizacii matochnyh arterij pri miomah matki. Patent RF № 2364335, A61V5/1473, A61K49/12, 20.08.2009. Russian.

9. Yudina TA, Manuhin IB, Tihomirov AL. Optimizaciya postembolizacionnogo perioda $u$ bol'nyh miomoj matki. Akusherstvo i ginekologiya. 2017; (12): 110-4. DOI: https:// dx.doi.org/10.18565/aig.2017.12.110-114. Russian.

10. Damirov MM, Shaxova OB, Sattarova ZI, Olejnikova ON. 
Sovremenny`e podxody $k$ diagnostike narushenij mikrocirkulyacii $\checkmark$ ginekologicheskoj praktike (obzor literatury). Zhurnal im. N.V. Sklifosovskogo "Neotlozhnaya medicinskaya pomoshh». 2016; (1): 40-4. Russian.

11. Krupatkin Al, Sidorov W. Lazernaya doplerovskaya floumetriya mikrocirkulyacii krovi: ruk-vo dlya vrachej. M.: Medicine, 2005: 126 s. Russian.

12. Palcev MA, Paukov VS, redaktory. Patologiya $\vee 2$ 2-h tomah: uchebnik. M.: GEOTAR-Media, 2010; 1024 s. Russian.

13. Sosin SA, Privorotskij VV, Zazerskaya IE, Kustarov VN. Prognosticheskie pri-znaki vy'razhennosti bolevogo sindroma posle èmbolizacii matochny'x arterij $u$ zhenshhin $s$ lejomiomoj matki. Ginekologiya. 2017; 19 (5): 30-3. DOI: 10.26442/20795696_19.5.30-33. Russian.

14. Nurmukhametova ET, Shlyapnikov ME. Arkhitektonika miomatoznykh uzlov $u$ zhenshchin. postupivshikh na lecheniye

\section{Литература}

1. Адамян Л. В., Серов В. Н., Сухих Г. Т., Филиппов О. С., редакторы. Клинические рекомендации. Акушерство и гинекология. Проблемы репродукции. Спец. вып. 2017; 23 (6).

2. Шаповалова А. И. Лейомиома матки и репродукция. Журнал акушерства и женских болезней. 2019; 68 (1): 93-101. https:// doi.org/10.17816/JOWD68193-101).

3. Доброхотова Ю. Э., редактор. Эмболизация маточных артерий. Спб: Экстен Медикал, 2013; 112 с.

4. Marín-Sánchez P, Sánchez-Ferrer ML. Conservative management of vesical-vaginal fistula after partial uterine and bladder necrosis due to embolization as a treatment for postpartum hemorrhage. Int Urogynecol J. 2015; 26 (5): 773-4. DOI: 10.1007/s00192014-2617-1.

5. Pillai AK, Kovoor JM, Reis SP, et al. Exposure of a Uterine Fibroid into the Small Bowl through Uteroenteric Fistula Presenting with Bowel Obstruction after Uterine Fibroid Embolization: Case Report with Histopathological Correlation. J Vasc Interv Radiol. 2016; 27 (5): 762-4. DOI: 10.1016/j. jvir.2015.11.047.

6. Yu Q, Gabriel G, Hoffman M, Sanampudi S, Jassim T, Raissi D. Uterine-sparing management of pyomyoma after uterine fibroid embolization. Radiol Case Rep. 2019 Jun 12; 14 (8): 1031-5. DOI: 10.1016/j.radcr.2019.05.009

7. Горюнова Т. В., Агапов В. К., Цвиркун В. В., ГолощаповАксенов Р. С., Скруберт В. С., Климов М. М., авторы; Горюнова Т. В., патентообладатель. Способ лечения миомы матки. Патент РФ №2289415, А61К35/14, 20.12.2006.

8. Пирогова В. И., Галанова 3. М., Гарипов Р. М., Мухаметвалеева Г. Р, Галимов О. В., Бузаев И. В., и др., авторы; Башкирский государственный медицинский университет, петентообладатель. Способ профилактики послеоперационных осложнений эмболизации маточных артерий при миомах матки. Патент РФ №2364335, A61B5/1473, A61K49/12, 20.08.2009.

9. Юдина Т. А., Манухин И. Б., Тихомиров А. Л. Оптимизация постэмболизационного периода у больных миомой матки. metodom embolizatsii matochnykh arteriy. Vestnik meditsinskogo instituta «Reaviz»: Reabilitatsiya, vrach i zdorovye. 2019; 2 (38): 48-54. Russian.

15. Musin II, Fatkullina IB, Gazizova GH, Popova EM, Molokanova AR. Primenenie lazernoj dopplerovskoj floumetrii i biologicheskoj obratn oj svyazi s cel'yu profilaktiki erozij setchatogo proteza. Prakticheskaya medicina. 2019; 17 (4): 88-91. DOI: 10.32000/2072-1757-2019-4-88-91. Russian.

16. Kozlov VI, Azizov GA, Gurova OA, Litvin FB. Lazernaya dopplerovskaya floumetriya $v$ ocenke sostoyanii i rasstrojstv mikrocirkulyacii krovi. Metodicheskoe posobie RUDN. Moskva, 2012; 32 s. Russian.

17. Nurmukhametova ET, Shlyapnikov ME. Diagnosticheskaya znachimost ocenki sostoyaniya perifericheskogo krovotoka posle e’mbolii matochny’x arterij. Prakticheskaya medicina. 2018; 16 (8): 106-10. Russian.

Акушерство и гинекология. 2017; (12): 110-4. DOI: https:// dx.doi.org/10.18565/aig.2017.12.110-114.

10. Дамиров М. М., Шахова О. Б., Саттарова З. И., Олейникова О. Н. Современные подходы к диагностике нарушений микроциркуляции в гинекологической практике (обзор литературы). Журнал им. Н. В. Склифосовского «Неотложная медицинская помощь». 2016; (1): 40-4.

11. Крупаткин А. И., Сидоров В. В. Лазерная доплеровская флоуметрия микроциркуляции крови: рук-во для врачей. М.: Медицина, 2005; 126 с.

12. Пальцев М. А., Пауков В. С., редакторы. Патология в 2-х томах: учебник. М.: ГЭОТАР-Медиа, 2010. 1024 с.

13. Сосин С. А., Приворотский В. В., Зазерская И. Е., Кустаров В. Н. Прогностические признаки выраженности болевого синдрома после эмболизации маточных артерий у женщин с лейомиомой матки. Гинекология. 2017; 19 (5): 30-3. DOI: 10.26442/2079-5696_19.5.30-33.

14. Нурмухаметова Э. Т., Шляпников М. Е. Архитектоника миоматозных узлов у женщин, поступивших на лечение методом эмболизации маточных артерий. Вестник медицинского института «Реавиз»: Реабилитация, врач и здоровье. 2019; 2 (38): 48-54.

15. Мусин И. И., Фаткуллина И. Б., Газизова Г. Х., Попова Е. М., Молоканова А. Р. Применение лазерной допплеровской флоуметрии и биологической обратной связи с целью просилактики эрозий сетчатого протеза. Практическая медицина. 2019; 17 (4): 88-91. DOI: 10.32000/2072-1757-2019-4-88-91.

16. Козлов В. И., Азизов Г. А., Гурова О. А., Литвин Ф. Б. Лазерная допплеровская флоуметрия в оценке состоянии и расстройств микроциркуляции крови. Методическое пособие РУДН. Москва. 2012, 32 с.

17. Нурмухаметова Э. Т., Шляпников М. Е. Диагностическая значимость оценки состояния периферического кровотока после эмболии маточных артерий. Практическая медицина. 2018; 16 (8): 106-10. 